$\begin{array}{llr}\text { KULTURA } & \text { POLSKA A KADEMIA NAUK } & \text { ISSN 0023-5172 } \\ \text { i } & \text { KOMITET SOCJOLOGI } & \text { 2300-195x } \\ \text { SPOLECLENSTWO } & \begin{array}{l}\text { INSTYT T STUDIÓW POLITYCZNYCH } \\ \text { 2019, nr 4 POLES IN THE WORLD OF LATE CAPITALISM }\end{array}\end{array}$
$\begin{array}{llllllll}\text { A } & \mathrm{R} & \mathrm{T} & \mathrm{I} & \mathrm{C} & \mathrm{L} & \mathrm{E} & \mathrm{S}\end{array}$
A N D
E $\quad S \quad S \quad A \quad Y \quad S$

MARCIN GOŃDA

Institute of Sociology, University of Lodz

\title{
TRANSNATIONAL CORPORATIONS AS A SOURCE OF CAREER AND BIOGRAPHICAL STABILISATION: THE CASE OF POLISH CORPORATE EMPLOYEES*
}

\section{INTRODUCTION}

Sociological analyses of professional career developments in Poland in the last decades have shifted their focus from the employment patterns typical of the socialist economy-which suffered from inefficient productivity and shortages of goods but at the same time guaranteed relatively stable working conditions and predictable promotion paths-to capitalist (neoliberal) labour regimes framed by principles of flexibility, employability, and competitiveness (Mrozowicki 2011; Strzelecki 2012; Giermanowska 2013; Gdula 2014). The inclusion of Poland's economy in globalisation, followed by the liberalisation of its economic rules, resulted in the dismantling of the institution of state-assured employment

Correspondence address: marcin.gonda@uni.lodz.pl; ORCID: 0000-0003-0940-8849

* This paper is the result of the research project Poles in the World of Late Capitalism: Changes of Biographical Processes in Terms of Professional Careers, Social Relations and Identity at the Time of System Transformation in Poland. The project was carried out in the Institute of Sociology, University of Lodz, in 2014-2018, and was financed by the Polish National Science Centre (NCN) within the OPUS scheme (grant no.: UMO-2013/11/B/HS6/01473). Members of the research team were as follows: Andrzej Piotrowski (head), Kamila Biały, Marcin Gońda, Karol Haratyk and Anna Rosińska. 
and in the increased flexibility of the labour market. These tendencies were justified by individualistic ideas of self-realisation and self-development, based on the constant necessity for people to prove their initiative, creativity, entrepreneurial attitude, and ability to cope with risk and uncertainty (Jacyno 2007). However, although there have been a significant number of analyses on changes in employment arrangements in post-socialist Poland, including papers on employees' experiences at the time of the systemic transformation (Biernacka 2009; Piorunek 2010; Biały 2015; Domecka 2016), the characteristics of working in the corporate environment seem not to have been thoroughly analysed.

The findings of the project Poles in the World of Late Capitalism, which is presented here, indicate that on the level of biographical processes the tensions of late capitalism associated with changes in the labour market (as well as social relations and identity) are particularly vivid in the corporate work organisation. ${ }^{1}$ Many studies suggest that in the present time of late capitalism, when social reality is framed by fluidity and heterogeneity, with fast and multidirectional changes in almost all areas of social life, work has lost its stabilisation feature and contributes to the already strong feeling of uncertainty and risk. The present paper is an attempt to discuss this claim and to answer the question of how these work-related dilemmas are being solved by contemporary participants of the corporate field. Do Polish employees perceive working in a corporation as coercion (the need to conform to unfavourable conditions) or as an opportunity (a chance to assure good prospects for the future)? Does work in a transnational corporation make people's lives even more inconsistent? Or to the contrary, are transnational corporations the only workplaces in which that coherence can be achieved?

\section{TRANSFORMATIONS OF WORK}

Currently, the radical transformation of forms of work organisation, and thus of individual biographies, can be observed. This causes a significant change in people's lives and, as many scholars argue, contributes to the overall sense of inconsistency. In earlier times, work (along with the

\footnotetext{
${ }^{1}$ In the project presented here we understand "transnational corporations" (TCNs) to be, in accord with D. Karcher's classic definition, enterprises that conduct business on a scale exceeding state borders. Even though many seemingly equivalent terms, such as "multinational company" or "global enterprise" can be found, we stick to the transnational one as it aptly indicates the corporations' abilities to operate across borders and their desire to play a leading role in globalisation (Dumała 1995: 198).
} 
traditional community, state, and family) ensured a person's life coherence and strongly determined identity. The institutionalisation of the life course led to the construction of predictable life trajectories and determined the type and scope of experiences characteristic for a given life phase (Kohli 1985). Biography almost invariably was framed by three stages related to professional involvement: the pre-vocational stage, which was dominated by education; the stage of professional activity; and the post-professional stage, which was associated with gradual withdrawal from the market (Piorunek 2010). The main feature of the labour market was the relative guarantee of permanent employment in a good market situation along with a known, predictable career pattern (Giddens 1991; Beck 1992; Sennett 1998; Boltanski, Chiapello 1999). A professional career was dependent on previous education choices and the individual was oriented toward increasing competences and skills in narrow, specialised fields. This "natural", vertical career path was accompanied by professionalisation and gradual "growing into" a specific profession. The Fordist system of production led next to replacement of a person's "profession" with the person's "employment" and "occupation," which connected the individual with the location of a collectively performed set of activities rather than with the individual's specific competences. In recent decades, however, when work is being more and more defined by processes of automatisation, informatisation, and de-territorialisation, employees are required to rapidly adapt and update their competences and skills (Rifkin 1995; Piorunek 2010; Strzelecki 2012). The lifelong relation with the profession (and the employer) has been replaced by the necessity for lifelong learning and retraining for the purpose of a nomadic style of employment. The result is tensions with still extant and culturally rooted expectations of the lasting validity of an individual's educational and professional status and the resultant claims as to the scope and durability of employment related to this status.

It is also claimed that at present no major stabilisation of employment can be expected. The state is slowly withdrawing from measures to ensure employment security and companies no longer provide employees with stable career paths. Even in a time of economic boom people are under the constant threat of unemployment and their professional careers are founded on the precarious requirement continually and flexibly to adapt their own professional profiles to the changing needs of the labour market. The traditional type of employment based on a relatively long-term employment contract has evolved to more fluid job arrangements that promote short- or fixed-term, project-based or task-based relations between 
the employer and the employee (Brown 2000; Standing 2010). The predominance of an unstable work environment not only leads to unstable professional careers but also contributes to an increase in an already high sense of biographical risk and ontological insecurity. On the other hand, in the context of the growing tendencies of individualisation in every sphere of life, the creation of an original biography becomes desirable or even necessary. In other words, the emphasis on individuality creates a need for personal achievements and decision-making at times when predictable and relatively certain patterns of life course (including professional life) are no longer valid (Giddens 1991; Beck 1992; Bauman 2000).

In these conditions of instability, unpredictability, and at the same time constant necessity to legitimise one's initiative and resilience, people are forced to redefine the concept of their careers. Since access to hierarchical careers has been hindered and traditional status indicators related to education and work are gradually weakening, people tend to search for substitute forms (multi-professionalism, self-employment, freelancing, etc.) and other career patterns, which often lead to blurring the boundaries between work and leisure time. In European and American sociological literature, several concepts about these new career tendencies can be found, including "protean career" (Hall 1976), "portfolio career" (Handy 1994), "boundaryless career" (Arthur 1994) and "post-corporate career" (Peiperl, Baruch 1997). The problem of employment changes has also attracted the attention of several Polish scholars. They write of the phenomena of precariousness (Mrozowicki 2016), junk contract employment (Mrozowicki et al. 2015), non-linear, fragmented career patterns (Domecka, Mrozowicki 2013; Róg-Ilnicka 2015), and "disenchantment" with flexibility (Strzelecki 2012; Giermanowska 2013). These features are differently experienced depending on the type of employment (unskilled or highly skilled workers, entrepreneurs, freelancers) (Domecka, Mrozowicki 2013; Haratyk et al. 2017), generation (Poławski 2012) or position in the class structure (Strzelecki 2012; Gdula 2014). What seems not to have been studied throughout, however, is the nature of working in a corporate environment.

Investigating the features of work in transnational corporations seems to be of great importance for several reasons. First, in a globalising economy, TCNs employ growing numbers of people. The share of jobs provided by entities of this type in Poland is also constantly increasing (GUS 2019). Second, transnational corporations act as forerunners of Westernising changes in the post-transformation Polish context. They are not only taking over more and more of the labour market but they 
are also enforcing neoliberal tendencies. They are the highest-ranking offspring of late capitalism and the flywheel of its development (Strange 1996; Dunning, Lundan 2008; Stawska 2014). Third, as anti-corporate advocates note, the rapid mobility of the different forms of capital generated by TCNs contributes to wage stagnation, growing unemployment, and increasing social inequalities (Crotty et al. 1998). These omnipotent enterprises have also taken from states the monopoly over the economic control of societies (cf. Sassen 1998). Other writers have underlined that even though the turnover of transnational corporations often exceeds national budgets and though they are recognisable as brands all over the world, they are ultimately without specific nationality and thus do not permanently connect specific people or even activities. These enterprises are types of networks with liquid, variable, and blurred boundaries and functions. They have ceased to be localised and community-based production organisations with which a person can easily identify (cf. Appadurai 1996). Finally, TCNs are worth studying not only because of their fundamental importance for the global economy, but also because of their impact on the biographies of individuals. Corporate requirements regarding competitiveness, creativity, and work efficiency are the basis for measuring employee usefulness. TCNs are known for demanding that their employees be fully committed and workaholic, and these are apparently the only strategies for career success or even keeping a given position (Biernacka 2009). TCNs are criticised for having dehumanised the work process and for fuelling the imbalance between work and life, with consequently devastating effects on the sphere of private life (Moore 2008).

Several empirical examples collected during the project confirm these findings. However, in other biographical stories, TCNs are presented in a more balanced way. The narrators perceive working in transnational corporations as highly demanding and excessively procedure-based but at the same time as making their experience of working more orderly and predictable. This seems particularly alluring for young adults who, as many studies indicate, after entering the job market "normalise" their employment, which was previously_naturally, if temporarily-precarious, uncertain, and highly flexible (Poławski 2012; Gdula 2014; Mrozowicki 2016). TCNs seem to be a good place to look for career and life stabilisation after such unfavourable work experiences. In analyses of their biographical paths it is worth referring to Donald Super's classic professional-development periodisation (1957; following Piorunek 2010). According to this concept people go through subsequent career phases. After a period of exploration and looking for their "own place" in the labour market (nor- 
mally after graduating from school) they achieve stabilisation, with clear job status and prospects for the future (25-45 years old). Later they reach the consolidation phase (45-64 years old) when the professional role is fully assimilated and professional maturity is achieved. Below, three empirical examples of looking for career stabilisation, as well as biographical stabilisation, in the corporate context will be presented.

\section{A PATH TO SOCIAL ADVANCEMENT}

Krystian, a 27-year-old employee of a transnational corporation in a large Polish city, has been studied in other parts of this volume and is an interesting example of someone who is focused on social advancement through work in a transnational corporation. The narrator grew up in a traditional family in a small town with limited job opportunities. The father (a clerk) and mother (a saleswoman) ended their education in secondary school. Later, they were convinced they had not "taken their chances" and consequently the family was under strong status pressure. As is typical for the working class (cf. Rodman, Voydanoff 1978; McDowell 2000), from the very beginning they projected their unfulfilled status aspirations on Krystian: they pushed him to finish university studies, which were supposed to guarantee him a better position than their own. Krystian studied extramurally (paying tuition) for a BA in management at a private university in a nearby city. Characteristically for working-class youth from provincial areas, who have less chance to be accepted to free and reputable studies in public universities, he did not attempt to study full time. He decided to attend a course of study that offered general competences rather than a more prestigious course of study (e.g., law, medicine, or engineering), which are more accessible to the upper classes (cf. Domański 2000). He did not have too high expectations as to his career, due to a fear of failure and also to a deep internalisation of his parents' attitude. He claims, however, it was his own choice, as he wanted to combine learning with work, which was to provide him with "cash for his own expenses". The work he did was hard physical labour, which was incompatible with the professional qualifications he intended to obtain at university but allowed him to prepare for the requirements of the job market:

During my studies I was already working. First I worked really physically. You know -19 years old, no job experience, fresh from graduating from secondary school. I couldn't really expect that some corporation would hire me and that I would deal with complicated topics, projects, or anything like that. I just didn't have a clue what it was... It was physical work in a warehouse, some drinks, alcohol, such things. And 
during holidays they hired young fellows, because in the summer, you know, there's a lot of work-thirsty people have to have a drink. And indeed it was hard. But it was also great to have some working experience to present in a CV later and to have this money - then you really begin to appreciate the value of money. It wasn't a great lot of money but enough to go somewhere with friends, to fill up the car and so on.

Combining higher education with work is a very popular strategy among young Polish people. It is a response to the conditions of the labour market, which has growing shortages of low qualified and temporary workers and thus recruits from students. Kristian's conscious decision "to have some working experience to present in [his] CV" is also an example of a common attitude among young people, who want to prepare themselves for when an employer - as the narrator anecdotally relates at another time - "requires a 25-year-old to have a university diploma and ten years of work experience". His part-time studies combined with work seemed to be a safeguard against the current occupational uncertainty.

When he graduated, he moved to a larger city to look for a better job. After completing an internship for graduates offered by a municipal office, he started working for an educational institution that offers vocational courses. This first full-time working experience appeared, however, to be very unpleasant. He was employed on a low-paying "junk contract" and bullied by his boss. Fortunately, after a year he found another job in a transnational company that outsources financial services. Despite his initial low expectations as to his future career, during the next four years he climbed subsequent ranks in the organisation until he was promoted to the position of "team leader", responsible for the work of five employees. This is how he reconstructs his career path:

Soon it will be four years in $X$ [name of the current employer], all the time in $X$, in the same team that works for the US. So my English skills were important. A nice combination of English plus skills in economics and IT, some other things. And it began to merge into such a nice thing, because at the beginning it was total chaos. Because in four years I managed to jump to the position of team leader. I don't know, maybe it's because I'm just a communicative person; I'm open to people. Maybe it's also my drawback because I want everyone to have a positive opinion about me. Not everyone has to like each other; but somehow I always want people to have a positive opinion about me. And it was fun at work; it was something completely new to me. But since I was really quite fast in computers I quickly began to learn and master these new processes. Because when I started working in this corporation, I had the aim that I wanted to learn it to such an extent that I wouldn't have to ask anyone about it - people were to ask me how to do it. And now if they don't know something, I hear they're saying "Go to Krystian, he will know what to do". So I started with the position "business data analyst," the lowest one you can get in the company. Later I became a so-called "ju- 
nior" and later a "senior." And then I was a "deputy specialist." It was fun, I got nice money and began to be responsible for processes in a more in-depth aspect; plus I was responsible for people because I had to report their errors to the customer, and then I had to explain them. But a nice element was that simply in cooperation with other people, we could specify what was the cause of the problem that had occurred and then we could possibly start thinking about something that would prevent it, right? A nice factor, because I began to cooperate with other people not only on equal terms but I also started to manage their time. And thanks to such initiatives people noticed me and so from this "deputy specialist" I jumped quickly to the position of "specialist." So it was quite, quite fine. It really started to go very well. A "specialist" is less involved in operational work, but more involved in documentation, getting it from people, in meetings, and discussing certain topics, so it began to be a nice management position. I was in this position about a year because the company has a policy that a person can be promoted only if the person spends at least 18 months in a lower position. But there are so-called exceptions; you need to have a performance evaluation. It's done every six months. And this is nice, because you get extra money, somewhere in the middle of the year, or at the end of it-it's always nice, money for holidays. A cool option. And as I said, I was in this position for 12 months and I had these two evaluations, both above average, so I was the perfect candidate for the position of team leader.

What makes this passage interesting is the way Krystian reconstructs his fast promotions in the company structure. His responsibilities are growing, so he spends more and more time at work and obediently performs his duties. He agrees to these demanding employment criteria as it enables him to reduce the initial constraints of his career development and makes rapid job promotion possible. This conformist pattern of behaviour paradoxically allows him to fit in well. He has no large expectations about his own agency, as working in such a highly proceduralised environment drives him to act. Importantly, however, he understands his agency not necessarily as the ability to implement his own plans but rather as having an impact on the activities he performs (a job that allows him to "manage" various domains) and on others (the position of "team leader" who can "manage their time"). This is how he explains his professional attitude towards relations with (future) subordinate employees:

I will try to separate what is professional and what is private, right? I don't want people in my team - a friend or someone - to think "Oh, God, we were mates and now he's mobbing me", right? You have to separate the two sensibly. After work we can go for a beer, laugh, talk, or do strange things, but at work you have to be professional and act in this way and no other. But that doesn't mean I have a stick up my ass, right? On the contrary, and I do go out with people often; we joke; we laugh; so they are relaxed in this work, but when necessary I reprimand them because something went wrong. Because someday I will also do these assessments. I will have to be very, 
very objective. I won't be able to look at the person on the basis of our acquaintance but only on the basis of his achievements at work, right?

The majority of the interview has a strong self-presentational character. Krystian focuses on his work and brags about his job successes. He is very absorbed by his work duties; there is a strong motive of professional achievement inspired by his parents, without any serious crises yet. For the time being, Krystian highly appreciates his professional situation. Shortly after entering the labour market he feels he is on a "rising wave". He spends more and more time at work, which proves that satisfaction can bring not only higher earnings, but also new obligations and control over other people. It seems, however, that despite the typical corporate slogans of "creativity" and "taking matters into your own hands" that he was taught, he is actually currently committed to reproducing and meeting the expectations of his bosses rather than on "creating." Krystian's "creativity" is rather not about demiurgical creation, but about "organising" and "arranging" daily responsibilities. This is a typical pattern of corporate work, which is framed by hierarchy-based management, procedurealisation, and standardisation. It is a paradox since the dominant discourse of late capitalism promotes attitudes of autonomy and self-realisation (cf. Jacyno 2007). It is a structural trait of late capitalism, which controls people not only through emerging procedures but also by developing a rhetoric of progress and creating a sense of agency. This sense of agency might also be developed through various substitute activities like "showing off." As Krystian notes in the previous passage, he wants "every person to have a positive opinion about me." In the corporate world (and in late capitalism) it is the social perception of how a person performs work and not the type of work itself that determines the person's prestige and influence. Work performance in the network is gaining importance, while work performance in the physical and organisational space is becoming less and less important. In other words, it could be paraphrased that "it does not matter what you do, but where and how you do it."

As discussed in the paper by Rosińska and Gońda in this volume, Krystian plans to establish a family. Apart from that, he does not have any long-term biographical plan of action (cf. Schütze 2008). His job-related dreams are limited to casual and basic plans of "getting by." His attitude seems typical for the working class; his lack of high expectations is caused by fear of failure. He is climbing the career ladder slowly and opportunistically so as not to make a mistake that would keep him in the (lower) class position of his parents. Thus he is strongly committed to working 
in a transnational corporation, which he values highly as a stabiliser in today's uncertain times. He is impressed by the possibilities for personal development there (international co-workers, earnings, clear criteria for further promotions). Krystian is the first person with a higher education in his family, which, as was noted, generates tensions in the context of strong status pressure. Unlike his parents, however, he is well aware that climbing the ladder currently is not necessarily guaranteed by a university education but depends rather on the place of work because, as he rhetorically asks himself, "where would I find better job possibilities and better money with my education and family background?" Krystian's attitude expresses the observed tendency towards the decomposition of traditional status indicators related to education and work. He is aware of the current invalidity of the long-lasting belief-rooted in the socialist system-in the value of education as the basic means of social advancement and a specific job as a guarantee of an individual's higher social status (cf. Sennett 1998). In this sense, for a person raised in a traditional and provincial family, working in a transnational corporation appears to be the best opportunity to raise own social position.

\section{SHELTER FROM TROUBLESOME WORKING CONDITIONS}

Rozalia's story is another example of a professional career that has been stabilised thanks to work in a transnational corporation. The biography of this 33-year-old financial specialist is also discussed in Rosińska and Gońda's paper in this volume because the main driving factor in her life is existential loneliness. Nonetheless, it is also worthwhile to set aside her relational sphere and to focus on her professional life.

As in Krystian's story, Rozalia's family members (the mother and grandmother by whom she was raised) had significant influence on her educational decisions. Despite her good command of foreign languages and having had some experience of professional internships abroad, after graduation from university she found her first job in the financial department of a public administration institution. She had considered starting her professional career abroad, but as she states:

It was a bad time to make any such decisions... radical ones. So I stayed in Poland. But I also had a problem finding a job that would interest me. I didn't want to work in a bank; I didn't want to be an accountant and basically after a year I did find a job in $X$ [a public sector institution]. Well, but then it turned out to be a torment.

The accountant position in the public sector did not satisfy her as it was poorly paid, time demanding, highly proceduralised, and without many 
prospects for the future. Deprived of motivation to act and discouraged by the job routine and bad working conditions, after a few years she returned to her initial plans and made up her mind to work abroad. She was determined to "spread her wings" in her profession, and not-as is often the case of Polish emigrants (Fihel et al. 2009) - below her qualifications. Even though it is widely believed that the public sector in Poland offers low wages but higher job security than private enterprises, Rozalia was looking not only for better wages but also other social security benefits that would guarantee her life stability:

I always wanted to leave. It's well known that Poland is not a paradise on earth and it's easier to live in the West when it comes to job security, health care, educationthat people are less stressed and therefore less aggressive in various everyday contacts, because they don't have to worry so much that they will lose their job soon...

Rozalia's emigration could be treated as an expression of generational experience, albeit for reasons that are not obvious. As already noted in the paper by Rosińska and Gońda, her emigration was not only motivated by material hardship and professional development plans but also by the need to keep a balance between the spheres of work and private life (cf. Benson, O'Reilly 2009), meaning mostly establishing a greater number of satisfactory and normatively important relations, as well as having "an interesting life." She chose to emigrate to Paris because, as she points out:

I wanted to go to Paris. I wanted to live abroad, but I thought that I wanted to leave Poland, my city, and to live there because there is a lot going on there-it's an interesting city - because I wanted to have an interesting life and... some work...it was supposed to be the hierarchy, so to speak...And I finished my studies in Poland, with an average command of French somehow. I didn't think I could get such a job as that, to tell the truth. It was above my qualifications. And, frankly speaking, I managed very well there thanks to various combinations... But I was more and more tired, more and more stressed, and when I took into account the fact that I was far away from family, from friends, I thought that it made no sense-because I went away to have an interesting life, not to work...

After a two-month intensive language course in France Rozalia found a very well-paid position as a financial auditor in a reputable law firm, which seemed to be-as she notes-an example of a "rare success story" for a person with limited experience on the international job market. However, during the following months her job duties grew excessively, so that she was spending up to 60 hours per week in the office. Despite being in, as she notes, a "supposedly more civilised country," the feeling of being exploited, which she had known in Poland and had wanted to escape from, returned again. Her job started to colonise her private life, the sphere she 
had initially hoped to expand while in France. She did not have enough free time to enjoy the culture of Paris, and she did not manage to build any meaningful relations with French people, or even within the Polish diaspora there:

In Paris, I went to a group called "Polish Women in Paris," but it was a different Polish environment in the sense that they were people who had been there for a long time and were somehow connected with that culture, or they were women who had families there, so they were also somehow connected... And I was left alone, so I felt that I didn't have any $100 \%$ contact with anyone...

In another place she adds:

It wasn't until my stay abroad that I realised that no matter how well you live there, and no matter how the situation here would frustrate you — what the political situation will be - and I try not to think about politics and try to know as little as possible so as not to get frustrated — and independently how this game is stupid, you still know that...Poland is your home because your family and friends are here. And that you don't have to explain anything to them all the time, like when you are abroad and they constantly ask you "What's it like in Poland?", because here you have a common background and some things are obvious...Because it does not matter how much you earn ... it's important not to earn below a certain level, because you are not able to live a dignified life and interesting life...because I am not complaining now about earnings, but in fact this trip was the most extreme, difficult experience, which, however, taught me a lot...

As a result, her period of emigration ended after one year. Her expectations as to better living conditions thanks to a supposedly stable and well-paid job were disappointed. Despite having satisfying wages and possibilities of promotion within the company, the excessive work was beyond her capabilities and negatively impacted her health. Being exhausted and discouraged she decided to return to Poland. Just as in the time before she went to France, she did not have job in Poland, but before long she managed to find a managerial position in a transnational corporation. The knowledge of several foreign languages and a brief but intensive experience of working abroad appeared to be a bargaining chip in wage negotiations with her new employer. At the moment of the interview she had been working there for over a year.

Rozalia presents her current job situation as a liberation from previous troublesome working conditions. Previously, she had treated work as a measure to secure her existence financially and, in the case of her emigration episode, as a tool to broaden her relational world. Despite the hardships of staying abroad, she does not consider her trip there to have been a failure but rather a formative experience. From that moment on, 
she finally felt that she had "life in my hands-that it depends on my own decisions." It also allowed her to organise her life by drawing clear boundaries between the sphere of work and the sphere of private life (work-life balance). Earlier, while still in France, she was able to sacrifice herself for her employer, but now she is not willing to engage so deeply: "I give as much as I can at work, one hundred percent, but nothing more; there is no sacrifice over that - very rarely some overtime work but nothing more." During the job interview for her present position she was determined to "fight for this principle I set up for myself" and so far the workload expected from her has not exceeded what was agreed upon.

In her story, the corporation appears not only as a stabiliser after bad experiences of working in the public sector (low-paid, highly proceduralised work without any prospects for promotion) and abroad (requiring too much physical and emotional effort). After these demanding job experiences, working for a corporation guarantees financial security and clear rules of promotion. She is aware of the generally unfavourable opinions people have about transnational corporations but she claims that paradoxically TCNs are the employers in Poland that most fully comply with the labour code. She relates stories of her friends on similar professional paths who have also found "safe haven" in transnational corporations because "they did not have to suffer because of low wages or fear whether they could have a child and go on leave." Furthermore, she is a human-rights and vegan activist and appreciates both the employee-friendly policies and ecological campaigns her company implements. She is certain that these activities are conducted to achieve better financial results for the company rather than to raise the employees' sense of satisfaction or to protect the environment, (cf. Blazovich et al. 2014), but "still it's better than the performance of our local companies, which are focused on achieving their financial goals at the lowest cost and without taking into account their employees' needs or the environment." Thus, in her narration, the transnational corporation is presented as an entity that gives her the opportunity to build stability for many years.

\section{MAINTAINING A WORK-LIFE BALANCE}

The third example of a transnational corporation becoming a guarantor of work-life balance is the story of Leszek, who is a 35-year-old IT specialist from a large Polish city. From his early years he was very interested in technical issues. He appeared to be a kind of prodigy; during his teenage years he was able to assemble a computer from parts or to develop new software. His parents discovered his talents quite early and, despite not be- 
ing knowledgeable about computers, gave him the support he needed and protected him from the "bad influence" of peers so that he could broaden his IT-related interests. He thus developed strong confidence in own skills early, so they could be further deepened thanks to education and, especially, job experience. Then, as he states, the "natural I was to study IT." Interestingly, during the first years of his engineering studies at a technical university he started to combine learning with working in one of the IT companies. In contrast to Krystian, his decision to enter the job market early was not due to the need for pocket money or getting new job experience but to "learn some practical things that simply had more to do with reality than studies." In the end it took him seven years (instead of five) to get his university diploma. He still considers that "it was a big success that I was strong enough to complete it taking into account the senselessness of those studies. But I promised my mom, so I did it."

Leszek has the ethos of a traditional engineer who is not only able to solve technical problems but also to understand and explain all the technical aspects of given objects. He is also much devoted to work. Once a task is to be done, he pays all his attention to finishing it. Since in his current job he works in a managerial position he always tries to select people with appropriate qualifications to achieve the goal. This is often impossible and thus he is critical of people who have only partial qualifications in a given area. His attitude is especially visible when he reminiscences about his university times and first job:

It was nice to work there; it was a pleasure. I was going to work - and you know how it is at work - in three months you learn more than in 15 years of studying [laughs]. And I worked in M. [an IT company] probably for six years. At the time I was working there, such an X. [name of a group of IT specialists] was established, a hobby group, where people are interested in IT technology and they meet to exchange knowledge. So I was also actively involved in creating this group and I was leading this group for some time. And I got bored, I mean maybe not so much bored but I'm generally allergic to people in the sense that I don't really like to babysit them. It simply transformed into a situation where I was asked all the time to "organise some session" or simply to "talk about something" and speaking to people is definitely not for me. I just hate babysitting and forcing people to do anything. If someone is not proactive, it just makes me really nervous... So after a while I just put it aside, I put aside all of these social activities.

These practices of distancing (cf. Domecka 2016) in answer to other people's incompetence were also the reason why he had to change his next jobs. Whereas other people look for a job to increase their salaries, Leszek (still well paid) was looking for a job environment that, as he notes, "would 
not insult my intelligence." As many other pieces of biographical evidence collected during the project show, this type of confidence in one's own professional qualifications and skills seems to be typical for engineers, especially those working in the IT sector. In a situation of great demand for IT specialists on the Polish labour market and the feeling of being, as Leszek notes, "indispensable for every company and every office" their expectations as to the public recognition of their importance are also high.

Since he has strong confidence in his knowledge he expects the same level of proficiency, engagement, and self-organisation from the people he deals with not only at work but also in everyday situations. This normalisation and ideologisation of his attitude results in his belief that others should follow his good example:

In our company I'm also involved in the recruitment process, because we don't want to leave such people to other companies. But after all you just have to choose someone, and these people are so terribly incompetent. And people are so, you know, unorganised and clumsy. It even annoys me - you know, you go to the store, and I'm very annoyed that people don't care that they're just standing in the middle and talking to someone, right? Well, if I have to tie my shoe, I go down the aisle and I tie my shoe, right? And people have a tendency - I don't know, maybe I'm strange, but it annoys memaybe not annoys but it amazes me... Well, it's difficult for me to say, you know why it annoys me, because theoretically people are different, right? Well, among other things, the core issue about this world is that people are different but the issue is that people tend not to see their imperfections. They don't see their mistakes but they are the first to point out others' mistakes, right?

On the other hand, despite having these technocratic and meritocratic attitudes, which are based on a conviction of one's qualifications and an effort to justify one's position in the social structure, Leszek seems to be aware of the mechanisms that frame social and political reality. For instance, he sees the privileged position of people working in this sector when he refers to a popular joke among his colleagues: "Last week I got fired. It was the worst twenty minutes of my life but then the head-hunter from another company called me and offered me a new position and a 20\% salary increase." Interestingly, despite being demanding towards other IT specialists and other people in general, he thinks that the wage discrepancies between IT and other sectors are too large.

Leszek has found some stabilisation at work and now he is not looking for other job offers. Normally he refuses recruiting companies offering him better wages in other companies. He only attends these job interviews from time to time in order "not to forget how it is." Like Krystian, at work he is a well-respected specialist to whom colleagues turn when 
they have any technical problems. This superiority status (his ability to solve problems for others) enhances his sense of agency. In a situation where society functions in a disorderly manner (as it consists of incompetent people), working in a corporation with its proceduralisation and well-organised structure is one of the few spheres where he finds order and coherence. On the one hand, he recognises many disadvantages of corporate-like management, including "sticking to the set plan and procedures when it no longer makes sense." He gives the example of when a computer in his office broke down and he was able to fix it alone the same day but, following the set procedures, he had to report this failure to the headquarters in another country. As a result, the exchange of the computer took several days and he sat idle at work. As a manager, however, he is responsible for co-creating procedures and thus he can somehow manage the fuzzy reality. Furthermore, thanks to the company's flat organisation structure, where successive levels of initiation and specialisation are not much related to hierarchical dependencies (due to the few levels of middle management) he can put his own ideas into practice. He seems to be a kind of demiurge and master (who does not respect any authorities) as well as an artist and creator (as programming is about creating) who knows best what to do:

It matters to me how I do my job or whether someone disturbs me or not. And okay, it sounds a bit nerdy but I have a problem in general -I don't recognise authorities. In the sense that for me you need to deserve my respect. If someone is called a boss it means nothing to me, right? Okay, maybe it's a bit wrong, because somehow he became the boss; he has some experience, etc. But you can become a boss in different ways, right? So you have to earn my respect. So I don't care if someone is doing business; he does it this way, it's super good and it's definitely good, and I can't undermine it, right?

On the other hand, working in the IT sector does not bring him a full sense of self-realisation. The activities that provide him with real satisfaction involve developing software for home automation systems. He is a master of technical issues so he can now have fun with the knowledge he possesses. At the same time, he is aware that he can achieve his objectives thanks to his job qualifications and the rapidly developing IT branch, which assures his financial and social status:

At work, it's always the same; there's always something to be done. Once it's more interesting, once it's less interesting. The most important thing for me is that apart from the fact that it's associated with my interests, well, first of all, it's well paid, so it allows you to realise yourself outside of work, right? Suddenly you just realise that you have the money to do your hobby, right? Let's say you want to develop a home automation system because it's an interesting topic and a trendy one, and you start developing a home automation system and it doesn't affect you much financially, right? 
This is probably the most important thing. Compared to the situation in other countries, salaries in IT in Poland allow me to live a normal life, as I would call it. Because I don't think that I'm earning some huge amount of money; it's just something that allows me to live peacefully and take care of [my] hobby. Something that people, I don't know, have in the UK when they do simple manual work, right?

Leszek sold a few software packages for home automation but he's not thinking about quitting his job in the IT corporation and transforming his hobby into a way of earning a living. In another part of the interview, when he is asked to detail his future plans, he reveals that he will try to stay in his present job. Even though there are no possibilities of developing his interests at work, the most important thing is that his current job provides him with satisfactory financial resources so that he can self-realise in other spheres:

I just don't care about further promotion possibilities. I could be promoted furtherI was promoted to a managerial position and I was quite good at it, but it was related to babysitting people and preparing just, you know, PowerPoint presentations or Excel tables and counting numbers to see whether everything is fixed. They would have to pay me really good money to do it again. So it's a bit like that. I don't know where to go to be able to develop faster, in a sense to be promoted, right? Because I can self-realise all the time in other areas, right? However, I'm unable to be precise about my plans, maybe-apart from starting my own business, which somehow does not really turn me on.

In summary, Leszek does not have any biographical action scheme (cf. Schütze 2008). He has a stable and well-paid job as well as strong confidence in his qualifications (being a demiurge and master at work), which also gives him a strong sense of certainty about his status. He can then self-realise and lead a happy life devoid of major worries.

\section{SUMMARY}

It is argued that individuals today lack stable tools to ensure overall life coherence. Work, which used to be a crucial foundation for a person's identity, is being dismantled by simultaneous liberalisation and flexibility processes. The sense of continuity and the predictability of work have been replaced by non-linear, fragmented career patterns. Even though many research findings suggest that work has lost its stabilising feature for individuals in today's world of fluidity and heterogeneity, biographical data collected within the project "Poles in the World of Late Capitalism" show that working in the specific conditions of transnational corporations may contribute to finding and maintaining this life coherence. The 
growing requirements of a dynamically changing, competitive, and flexible labour market promote the individual creation of professional biographies. Transnational corporations, with their clear rules of promotion, and their provision of relatively good salaries and access to other social benefits (vacation, sick leave, employee-friendly policies etc.), are seen as enterprises that, contrary to general conviction, provide more stable working conditions than other employers in the precarious labour market. TCNs also seem safe to many people after their troublesome experiences of working in poorly paid sectors (e.g., public administration) or after a period of emigration. Corporate-like jobs are also becoming more and more accessible for people entering the labour market and thus could become a basic path to social advancement. In a situation where traditional status indicators such as education and a profession are losing their importance, working in a transnational corporation may provide an essential confidence to underpin a person's social position. Even though working in a transnational corporation is often demanding and leads to blurring the boundaries between the sphere of work and the sphere of private life, it may provide an opportunity for career and life stabilisation in the long-term perspective.

\section{REFERENCES}

Appadurai, Arjun. 1996. Modernity at Large: Cultural Dimensions of Globalization. Minneapolis: University of Minnesota Press.

Arthur, Michael B. 1994. "The boundaryless career: A new perspective for organizational inquiry." Journal of Organizational Behavior 15(4): 295-306.

Bauman, Zygmunt. 2000. Liquid Modernity. Cambridge: Polity.

Beck, Ulrich. 1992. Risk Society: Towards a New Modernity. London: Sage.

Biały, Kamila. 2015. "Professional biographies of Polish corporation workers in the late capitalist world." Przegląd Socjologii Jakościowej 11(4): 46-67.

Biernacka, Maja. 2009. Człowiek korporacji. Od normatywizmu do afirmacji własnego ja. Warszawa: Scholar.

Blazovich, Janell L., Katherine T. Smith, Murphy Smith. 2014. "Employee-friendly companies and work-life balance: Is there an impact on financial performance and risk level?" Journal of Organizational Culture, Communications and Conflict 18(2): 1-14.

Boltanski, Luc, Ève Chiapello. 1999. Le nouvel esprit du capitalisme. Paris: Gallimard.

Brown, Bettina Lankard. 2000. “Changing Career Patterns.” Eric Digest no. 219.

Domański, Henryk. 2000. "Selekcja ze względu na pochodzenie społeczne do szkoły średniej i na studia wyższe.” Nauka i Szkolnictwo Wyższe 2(16): 97-108.

Domecka, Markieta. 2016. "Biographical experiences of post-socialist transformation in corporate business: doing the neoliberal path.” Przeglad Socjologii Jakościowej 12(2): 56-77.

Domecka, Markieta, Adam Mrozowicki. 2013. "Linking structural and agential powers: A realist approach to biographies, careers and reflexivity." In: Adam Mrozowicki, Jeffrery 
David Turk, Markieta Domecka (eds.). Realist Biography and European Policy: An Innovative Approach to European Policy Studies. Leuven: Leuven University Press: 191-213.

Dumała, Andrzej. 1995. "Uczestnicy transnarodowi - podmioty niezależne czy kontrolowane przez państwa?” In: Edward Haliżak, Irena Popiuk-Rysińska (eds.). Państwo we wspótczesnych stosunkach międzynarodowych. Warszawa: Scholar: 191-211.

Dunning, John H., Sarianna M. Lundan. 2008. Multinational Enterprises and the Global Economy. Cheltenham UK: Edward Elgar.

Fihel, Agnieszka, Paweł Kaczmarczyk, Nina Wolfeil, Anna Zylicz. 2009. Brain Drain, Brain Gain and Brain Waste. In: Herbert Brücker (ed.). Labour Mobility within the EU in the Context of Enlargement and the Functioning of the Transitional Arrangements. Final report. Nüremberg: European Integration Consortium: 89-103.

Gdula, Maciej. 2014. "Klasa średnia i doświadczenie elastyczności.” Polityka Społeczna 5-6: $40-45$.

Giddens, Anthony. 1991. Modernity and Self-Identity: Self and Society in the Late Modern Age. Cambridge: Polity Press.

Giermanowska, Ewa. 2013. Ryzyko elastyczności czy elastyczność ryzyka. Instytucjonalna analiza kontraktów zatrudnienia. Warszawa: Wydawnictwa Uniwersytetu Warszawskiego.

GUS. 2019. "Grupy przedsiębiorstw w Polsce w 2017 roku.” Warszawa: GUS. (https://stat. gov.pl/obszary-tematyczne/podmioty-gospodarcze-wyniki-finansowe/przedsiebiorstwa -niefinansowe/grupy-przedsiebiorstw-w-polsce-w-2017-roku,14,10.html [accessed 31.08. 2019]).

Hall, Douglas T. 1976. Careers in Organizations. Pacific Palisades: Goodyear.

Handy, Charles. 1994. The Empty Raincoat: Making Sense of the Future. London: Arrow Business.

Haratyk, Karol, Kamila Biały, Marcin Gońda. 2017. "Biographical meanings of work: The case of a Polish freelancer.” Przegląd Socjologii Jakościowej13(4): 136-159.

Jacyno, Małgorzata. 2007. Kultura indywidualizmu. Warszawa: Wydawnictwo Naukowe PWN.

Kohli, Martin. 1985. "Die Institutionalisierung des Lebenslaufs. Historische Befunde und theoretische Argumente." Koellner Zeitschrift fuer Soziologie und Sozialpsychologie 37: 1-29 .

McDowell, Linda. 2000. "Learning to serve? Employment aspirations and attitudes of young working-class men in an era of labour market restructuring." Gender, Place and Culture: A Journal of Feminist Geography 7(4): 389-416.

Moore, Fiona. 2007. "Work-life balance: contrasting managers and workers in an MNC." Employee Relations 29(4): 385-399.

Mrozowicki, Adam. 2011. Coping with Social Change: Life Strategies of Workers in Poland's New Capitalism. Leuven: Leuven University Press.

Mrozowicki, Adam. 2016. "Normalisation of precariousness? Biographical experiences of young workers in the flexible forms of employment in Poland." Przeglad Socjologii Jakościowej 12(2): 94-112.

Mrozowicki, Adam, Agata Krasowska, Mateusz Karolak. 2015. “'Stop the Junk Contracts!' Young Workers and Trade Union Mobilisation against Precarious Employment in Poland." In: Andy Hodder, Kretsos Lefteris (eds.). Young Workers and Trade Unions. London: Palgrave Macmillan: 123-141.

Peiperl, Maury, Baruch Yehuda. 1997. "Back to square zero: The post-corporate career." Organizational Dynamics 25(4): 6-22. 
Piorunek, Magdalena. 2010. "Od stabilizacji do chaosu zawodowego. Scenariusze biografii zawodowych etapu średniej dorosłości.” Studia Edukacyjne 14: 67-89.

Poławski, Paweł. 2012. "Precarious Generation on the Polish Labour Market." Polityka Spoteczna 1: 15-22.

Rifkin, Jeremy. 1995. The End of Work: The Decline of the Global Labor Force and the Dawn of the Post-Market Era. New York: G.P. Putnam's Sons.

Rodman, Hyman, Patricia Voydanoff. 1978. "Social Class and Parents' Range of Aspirations for Their Children." Social Problems 25(3): 333-344.

Róg-Ilnicka, Joanna. 2015. "'Career by choice' or 'career by chance': The determinants of flexible professional biographies.” In: Adam Mrozowicki, Elżbieta Kolasińska, Joanna Róg-Ilnicka (eds.). Forum Socjologiczne. Special Issue: Social Boundaries and Meanings of Work in the 21st-Century Capitalism. Wrocław: Wydawnictwo Uniwersytetu Wrocławskiego: $213-223$.

Sassen, Saskia. 1998. Globalization and Its Discontents. New York: The New Press.

Schütze, Fritz. 2008. Biography Analysis on the Empirical Base of the Autobiographical Narratives: How to Analyse Autobiographical Narrative Interviews. Part I: INVITE—Biographical Counselling in Rehabilitative Vocational Training. Further Educational Curriculum. EU Leonardo da Vinci Programme ( http://www.zsm.ovgu.de/zsm_media/Das+Zentrum/Forschungsprojekte/INV ITE/B2_1-p-140.pdf).

Sennett, Richard. 1998. The Corrosion of Character: The Personal Consequences of Work in the New Capitalism. New York: Norton.

Standing, Guy. 2011. The Precariat: The New Dangerous Class. London-New York: Bloomsbury Academic.

Stawska, Joanna. 2014. "Inwestycje krajowe oraz bezpośrednie inwestycje zagraniczne w Polsce w świetle rozwoju polskiej gospodarki." Studia Europejskie/Studies in European Affairs 1: 91-108.

Strange, Susan. 1996. The Retreat of the State: The Diffusion of Power in World Economy. Cambridge: Cambridge University Press.

Strzelecki, Jan. 2012. "Postfordowska narracja o pracy i jej klasowe odmiany." In: Maciej Gdula, Przemysław Sadura (eds.), Style życia i porządek klasowy w Polsce, Warszawa: Scholar: 87-116.

Super, Donald E. 1957. The Psychology of Careers. New York: Harpers.

\section{Abstract}

This paper discusses contemporary transformations in the way work is organised and the consequences for the stability of careers and biographies. It debates the widely held belief that organised and predictable life-course paths (including professional careers) have ceased to exist and that work itself has lost its stabilising quality. Biographical data collected among Polish employees of transnational corporations within the project "Poles in the World of Late Capitalism" proves that even though transnational corporations are widely criticised for propelling neoliberal tendencies in the global economy, they provide a means of protecting their employees against today's uncertainty and occupational risk. Three empirical cases are presented to show how work in a transnational corporation may contrib- 
ute to achieving and maintaining stability for persons who have had troublesome experiences of working in other sectors of the labour market.

Key words: transnational corporation, career stability, biographical stability, biography, Poland

\author{
KORPORACJE TRANSNARODOWE JAKO ŹRÓDŁO \\ STABILIZACJI ZAWODOWEJ I BIOGRAFICZNEJ: \\ PRZYPADEK POLSKICH PRACOWNIKÓW KORPORACJI \\ Marcin Gońda \\ (Uniwersytet Łódzki)
}

\begin{abstract}
Abstrakt
W artykule omawiane są współczesne przemiany organizacji pracy i ich konsekwencje dla kariery i stabilizacji biograficznej. Autor podejmuje przy tym dyskusje $z$ rozpowszechnionym wśród badaczy twierdzeniem, że zorganizowane i przewidywalne ścieżki życia (w tym kariery zawodowej) przestają istnieć, a sama praca utraciła funkcję stabilizacji biografii. Wyniki badań biograficznych przeprowadzonych wśród polskich pracowników korporacji transnarodowych w ramach projektu „Polacy w świecie późnego kapitalizmu” pokazują jednak, że — mimo krytyki, która jest wymierzona $\mathrm{w}$ korporacje jako podmioty upowszechniające neoliberalne tendencje $\mathrm{w}$ światowej gospodarce - przedsiębiorstwa te oferują różne możliwości ochrony przed dzisiejszą niepewnością i ryzykiem zawodowym. W artykule przedstawiono trzy dowody empiryczne wskazujące, w jaki sposób praca w międzynarodowej korporacji może przyczynić się do osiągnięcia i utrzymania stabilności biograficznej po trudnych doświadczeniach w innych obszarach rynku pracy.
\end{abstract}

Stowa kluczowe: korporacje transnarodowe, stabilność zawodowa, stabilność biograficzna, biografia, Polska 